NASA

Technical Memorandum 107193
Army Research Laboratory Technical Report ARL-TR-1065

\title{
Performance Benefits for Wave Rotor-Topped Gas Turbine Engines
}

Scott M. Jones

Lewis Research Center

Cleveland, Ohio

and

Gerard E.Welch

Vehicle Propulsion Directorate

U.S. Army Research Laboratory

Lewis Research Center

Cleveland, Ohio

Prepared for the

41st Turbo Expo '96

sponsored by the International Gas Turbine Institute of

the American Society of Mechanical Engineers

Birmingham, United Kingdom, June 10-13, 1996
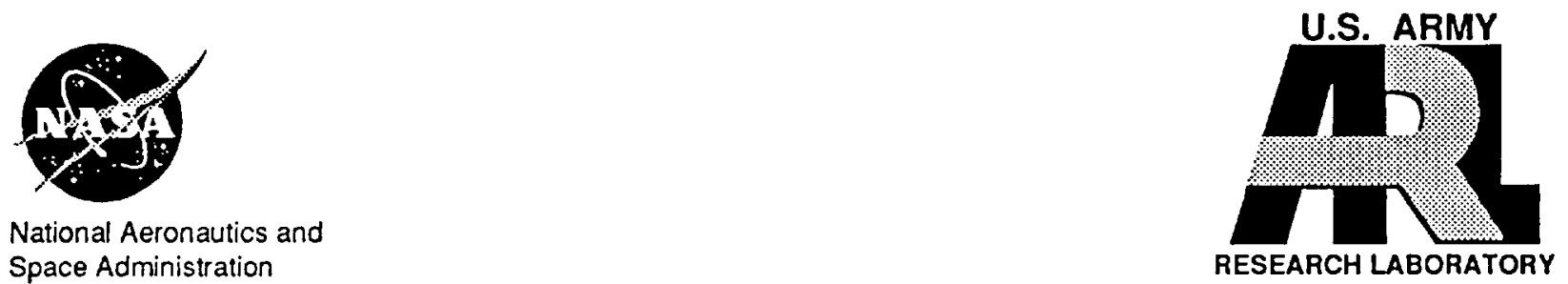


\section{PERFORMANCE BENEFITS FOR WAVE ROTOR-TOPPED GAS TURBINE ENGINES}

\author{
Scott M. Jones \\ NASA Lewis Research Center \\ Aerospace Analysis Office \\ 21000 Brookpark Road, M/S 77-2 \\ Cleveland, Ohio 44135 U.S.A. \\ phone: (216) $977-7015$ \\ fax: (216) $977-7008$ \\ e-mail: sjones@spitfire.lerc.nasa.gov
}

\author{
Gerard E. Welch \\ U.S. Army Research Laboratory \\ Vehicle Propulsion Directorate \\ 21000 Brookpark Road, M/S 77-6 \\ Cleveland, Ohio 44135 U.S.A. \\ phone: (216) 433-8003 \\ fax: (216) 433-3918 \\ e-mail: towelch@ephesus.lerc.nasa.gov
}

\begin{abstract}
The benefits of wave rotor-topping in turboshaft engines, subsonic high-bypass turbofan engines, auxiliary power units, and ground power units are evaluated. The thermodynamic cycle performance is modeled using a one-dimensional steady-state code; wave rotor performance is modeled using one-dimensional design/analysis codes. Design and off-design engine performance is calculated for baseline engines and wave rotor-topped engines, where the wave rotor acts as a high pressure spool. The wave rotorenhanced engines are shown to have benefits in specific power and specific fuel flow over the baseline engines without increasing turbine inlet temperature. The off-design steady-state behavior of a wave rotor-topped engine is shown to be similar to a conventional engine. Mission studies are performed to quantify aircraft performance benefits for various wave rotor cycle and weight parameters. Gas turbine engine cycles most likely to benefit from wave rotor-topping are identified. Issues of practical integration and the corresponding technical challenges with various engine types are discussed.
\end{abstract}

\section{NOMENCLATURE}

APU = auxiliary power unit

$\mathrm{CPR}=$ compressor pressure ratio

$\mathrm{GG}=$ gas generator

$\mathrm{HPC}=$ high pressure compressor

$\mathrm{HPT}=$ high pressure turbine

LPC $=$ low pressure compressor

LPT = low pressure turbine

$\mathrm{OPR}=$ overall pressure ratio: $\left(\mathrm{P}_{3} / \mathrm{P}_{\mathbf{2}}\right)$

$\mathrm{PR}=$ pressure ratio

$\mathrm{PR}_{\mathrm{w}}=$ wave rotor pressure ratio: $\left(\mathrm{P}_{4 \mathrm{~A}} / \mathrm{P}_{3 \mathrm{~A}}\right)$

$\mathrm{SFC}=$ specific fuel consumption
TOGW = aircraft takeoff gross weight

$T R=$ temperature ratio

$T_{R_{w}}=$ wave rotor temperature ratio: $\left(T_{4 A} / T_{3 A}\right)$ (also equal to $T_{4 B} / T_{3}$ )

WOPR $=$ wave rotor-topped engine overall pressure ratio: $\left(\mathrm{P}_{3 \mathrm{~B}} / \mathrm{P}_{\mathrm{a}}\right)$

Cycle station subscripts:

$\mathrm{a}=$ ambient conditions

$3=$ (high pressure) compressor exit

$3 \mathrm{~A}=$ wave rotor inlet port

$3 \mathrm{~B}=$ burner inlet duct

4 = burner outlet duct

$4 \mathrm{~A}=$ wave rotor outlet port

$4 \mathrm{~B}=$ (high pressure) turbine inlet

41 = turbine rotor inlet

\section{INTRODUCTION}

The wave rotor is a turbomachine consisting of a rotating annulus divided into axial passages with stationary ducts, or ports, delivering flow to and from the wave rotor (Fig. 1). The number, circumferential location, and thermodynamic conditions of these ports determine the wave rotor cycle. During "steady-state" operation, the flow through the rotating axial passages is alternately exposed to each inlet and outlet port, creating unsteady compression and expansion waves which propagate axially along the passages. Although this wave propagation is unsteady, it is also periodic. This periodic nature allows the wave rotor inlet and outlet flow to remain steady, creating the potential for the wave rotor to be included as part of a steady flow device such as a gas turbine engine. Furthermore, because the wave rotor passages are alternately exposed to hot and cold flows the mean rotor temperature is significantly lower than the peak cycle temperature. This "self-cooling" feature enables topping without increasing the temperature of the flow to the turbines. 
The wave rotor is not new; it has been proposed for various applications ranging from stationary power plants to a topping cycle for vehicle gas turbine engines. Previous work in this area has been reported by Taussig and Hertzberg (1984), Taussig (1984), and Shreeve and Mathur (1985).

With any new or unconventional technology, cycle and systems studies are the first step in determining the potential impact of that technology on system performance. This paper re-examines wave rotor-topping for gas turbine engines. The benefits of wave rotortopping for turboshaft engines, subsonic high-bypass turbofan engines, auxiliary power units, and ground power units as well as challenges and risks associated with the various wave rotor applications are discussed. In this work, emphasis is placed on wave rotor performance in the turboshaft and turbofan propulsion systems although the wave rotor may be better suited to other applications.

\section{WAVE ROTOR GENERAL INFORMATION}

As mentioned previously, port location and number determine the wave rotor thermodynamic cycle. As shown in Fig. 2, the fourport wave rotor considered here has a port from the compressor (port $3 \mathrm{~A}$ ), a port leading from the wave rotor to the burner (port 3B), a port from the bumer back to the wave rotor (port 4), and a port to the turbine (port 4A). This four-port wave rotor cycle is designed to provide a pressure gain with zero net shaft work. The four-port wave rotor is, in theory, easily incorporated into a gas turbine engine with the addition of transition ducts located between the compressor exit and port $3 \mathrm{~A}$ and between port $4 \mathrm{~A}$ and the turbine inlet. The two remaining wave rotor ports are connected to the burner. In addition, the performance benefits of a four-port pressure gain cycle are readily quantified for the various applications considered.

A simplified description of how this four-port cycle operates is as follows. The flow from port $3 \mathrm{~A}$ enters the wave rotor where it is compressed and exits the wave rotor via port 3B. The flow then enters the burner where it is heated to high temperature before reentering the wave rotor from port 4 . Inside the rotor, the flow expands as it compresses the incoming flow. Finally, the flow exits the rotor via port $4 \mathrm{~A}$ at a higher total pressure and total temperature than it entered the wave rotor. The peak pressure occurs in port $3 \mathrm{~B}$ and is typically $3-4$ times the pressure at port $3 \mathrm{~A}$. The peak cycle temperature occurs in port 4 and is $2-3$ times the port $3 A$ temperature. However, due to the high rotational speed of the rotor, the axial passages are rapidly exposed to both hot $\left(T_{4}\right)$ and cold $\left(T_{3 A}\right)$ flows and therefore the rotor assumes a mean temperature significantly less than $T_{4}$. This mean temperature is estimated to be close to $T_{A A}$ and allows the wave rotor to top turbine-inlettemperature-limited cycles.

The primary indicator of the four-port pressure-gain wave rotor performance is $\mathrm{PR}_{\mathrm{w}}$, the ratio of port $4 \mathrm{~A}$ total pressure to port $3 \mathrm{~A}$ total pressure. This pressure ratio is primarily a function of the wave rotor temperature ratio (port $4 \mathrm{~A}$ total temperature to port $3 \mathrm{~A}$ total temperature, or $\mathrm{TR}_{\mathrm{w}}$ ). Figure 3 shows the projected wave rotor performance as a function of $\mathrm{TR}_{\mathrm{w}}$. The data in Figure 3 was calculated by Welch, et al., (1995) and assumes values for other wave rotor variables such as mass flow rate and rotor rotational speed. It can be seen that the wave rotor can boost total pressure by $40 \%$ with a temperature ratio of about 3 .
The wave rotor can be used in conjunction with a burner as part of a gas turbine engine. In this case $T_{3}$ is assumed equal to $T_{3 A}$, and $T_{4 A}$ is assumed equal to $T_{4 B}$. In such a case, $T_{3 A}$ is determined by $P_{3}$ or OPR while $T_{4 A}$ is equal to the turbine inlet temperature. In order to maximize wave rotor performance (i.e., $P_{w}$ ) in an engine, then, a low OPR and a high turbine inlet temperature is required for a large $\operatorname{TR}_{\mathbf{w}}$. Historically, the trend in gas turbine engines has been toward rising OPR and $T_{41}$ due to technology and materials advances. Therefore, most gas turbine engines have a temperature ratio $T_{48} / T_{3}$ equal to 1.75-2.25 and a maximum wave rotor pressure ratio between 1.10-1.25 can be expected for these engines.

\section{METHOD OF ANALYSIS \\ Wave Rotor Analysis}

Although wave rotor pressure ratio is heavily dependent upon $T_{\mathrm{w}}$, variables specific to the wave rotor design, such as length, rotational speed, number of axial passages, and mass flow rate also affect $P R_{w}$ due to frictional losses, passage opening and closing losses, and other real-world effects. The design point wave rotor performance is determined from a one-dimensional design/analysis model (Welch, 1996). This model uses mass and energy balances, one-dimensional gas dynamics to model wave processes that effect energy exchange within a passage, and entropy production models to account for losses in boundary layer flows, separated flows, shock waves, and non-uniform port flow field mixing.

Another one-dimensional design/analysis model is used to calculate off-design wave rotor performance. Paxson (1993) has verified this model using experimental data. This model calculates off-design performance by solving the unsteady viscous flow field in an axial passage for time-constant inlet and outlet port conditions. The model accounts for losses due to gradual passage opening (and closing), viscous effects, heat transfer effects, leakage, and nonuniform port flow field mixing. The output of the code is used to create a wave rotor operating "map". This map is a table of $\mathbf{P R}_{w}$ as a function of off-design values of wave rotor RPM, wave rotor mass flow rate, and heat addition in the burner. Both the design point and off-design models include the burner pressure drop as part of the wave rotor performance calculation.

In some cases the wave rotor performance is "penalized". Typically, gas turbine engines use high pressure compressor bleed flow for turbine cooling. In wave rotor-topped cycles the turbine inlet total pressure is higher than the compressor exit total pressure $\left(\mathrm{P}_{4 \mathrm{~B}}>\right.$ $P_{3}$ ), and the peak cycle pressure occurs within the wave rotor. This means that in order to cool the first turbine stage, flow must be taken from a high pressure port of the wave rotor (port 3B in this case). Since this bleed flow is no longer available to do work in the remaining part of the wave rotor, the overall wave rotor performance is reduced or "penalized". The amount of the performance drop is proportional to the percentage of bleed flow required. Figure 4 shows the percentage decrease in wave rotor pressure gain as a function of the amount of compressor flow required for turbine cooling. The graph shows that a cooling flow of $20 \%$, not uncommon in modern gas turbines, reduces wave rotor pressure gain by approximately $50 \%$ (e.g. PR $_{w}$ goes from 1.20 to 1.10 ). In addition, wave rotors with lower performance appear to be slightly more sensitive to removing flow from the wave rotor as shown by the steeper slopes for the lower $\mathrm{TR}_{w}$ cycles. 


\section{Cycle Analysis}

The cycle performance is calculated using a one-dimensional steady-state thermodynamic cycle analysis code. The NASA Engine Performance Program (NEPP) allows the user to model virtually any kind of gas turbine engine cycle through the use of components which can be placed in any order to create the desired cycle (Klann and Snyder, 1994). For this study, a new component subroutine was added to NEPP. This new subroutine models the wave rotor component as a combination of a wave rotor and a burner, similar to that shown in Fig. 2. The wave rotor component has only one inlet flow station (station $3 \mathrm{~A}$ ) and one outlet flow station (station 4A) and therefore acts similar to a burner with a pressure gain. Because the wave rotor component in NEPP has only one inlet and one outlet flow station, it does not have allowance for bleed flow in its configuration. Because some of the study engines require cooling, the cooling flow for the wave rotor-topped engines is taken from the compressor (just as it is for the baseline engines), but the cooling-penalized wave rotor performance is used. This creates a slight error as the enthalpy of the cooling flow is lower than it would be if it were taken from the wave rotor.

In order to determine the benefit of wave rotor-topping, a baseline engine type along with representative cycle parameters is chosen and modeled. Once the baseline engine has been created, the wave rotor-enhanced engine model is created by replacing the burner component of the baseline cycle with the wave rotor component. Care is taken to make sure all the other component inputs are unchanged whenever possible. In order for reasonable performance comparisons to be made, the turbine inlet temperature $\left(T_{48}\right)$ and $O P R$ of the enhanced engine are kept the same as the baseline unless stated otherwise. In addition, pressure drops of $2 \%$ are added to the duct components immediately fore and aft of the wave rotor. These pressure drops account for the transition ducts that go from the compressor exit to port $3 \mathrm{~A}$ and from port $4 \mathrm{~A}$ to the turbine inlet. For the wave rotor-enhanced cycles, the burner pressure drop is accounted for in the wave rotor pressure ratio and is greater than the burner pressure drop of the baseline.

\section{Engine Weight and Aircraft Gross Weight Analysis}

The weight and dimensions of the turbofan engines is estimated by the WATE code (Onat and Klees, 1979). This code has been considerably enhanced from its original version. Using key component design variables in a preliminary design approach, the WATE code determines the weight of each engine component. The overall estimated engine weight is accurate to $5 \%$. The weight of the wave rotor component is not calculated by the WATE code. A rough calculation of the weight of the wave rotor for the turbofan application is made based on estimated thickness of the rotor casing, rotor materials, and required ducting.

The aircraft mission and sizing analysis is performed by the Flight Optimization System (FLOPS) code, which uses as inputs the engine performance data, a mission profile, and aircraft description including weights, aerodynamics, and geometry (McCullers, 1984). The aircraft model and mission used for this study is similar to the Boeing 777 subsonic transport aircraft. The mission profile consists mainly of a climb to $33000 \mathrm{ft}(10000 \mathrm{~m})$ at Mach 0.83 , a bestBreguet-altitude cruise, and a descent with a total aircraft range of $6500 \mathrm{~nm}(12000 \mathrm{~km})$. The aircraft carries 300 passengers and requires two engines rated at about $90000 \mathrm{lbs}(400 \mathrm{kN})$ thrust each. For this study the aircraft wing loading and the aircraft thrust-toweight are kept constant rather than perform an aircraft sizing thumbprint for each engine and weight variation.

\section{RESULTS AND DISCUSSION Turboshatt Engines}

Schematics of the baseline and the wave rotor-topped turboshaft configurations are shown in Fig. 5. The baseline engine consists of a conventional gas generator (compressor, burner, and turbine) on one shaft and a power turbine on a separate shaft. The wave rotor-topped turboshaft replaces the bumer component with the wave rotor/burner component. Figure 6 shows the increase in design point shaft power possible for wave rotor-enhanced turboshaft engines of varying compressor pressure ratio and $\mathrm{T}_{4 \mathrm{~B}}$. The wave rotor pressure ratio for each engine is determined from the curve in Fig. 3 and varies from $P_{\mathrm{w}}=1.095$ for the $C P R=50, \mathrm{~T}_{4 \mathrm{~B}}=2880 \mathrm{R}(1600 \mathrm{~K})$ design to $\mathrm{a}$ $P_{\mathrm{W}}=1.500$ for the $C P R=5, \mathrm{~T}_{4 \mathrm{~B}}=3240 \mathrm{R}(1800 \mathrm{~K})$ design. The mass flow for all the engines is $22 \mathrm{lb} / \mathrm{s}(10 \mathrm{~kg} / \mathrm{s})$, but the results are qualitatively applicable to turboshafts of any mass flow. For a given $\mathrm{T}_{4 \mathrm{~B}}$, increasing compressor efficiency has a very small beneficial effect due to the resultant decrease in $\mathrm{T}_{3}$ and subsequent increase in $T_{\mathrm{w}}$. As expected, the engines with the lowest $C P R$ and highest $T_{4 B}$ receive the highest benefit from wave rotor-topping due to their higher wave rotor pressure ratios. These results assume no cooling flow taken from the wave rotor. Because turbine cooling is generally required for turbine inlet temperatures exceeding approximately 2160 $\mathbf{R}(1200 \mathrm{~K})$, these enhanced engines will have to rely on some unconventional cooling scheme in order to achieve the performance benefits shown. This scheme could be an additional compressor to pressurize only the cooling flow or a cooling method that does not require the cooling flow pressure to be higher than the turbine inlet pressure.

Should cooling flow be taken from the wave rotor, the $\mathrm{PR}_{\mathrm{w}}$ (and subsequent cycle performance benefit) suffers. In addition, if this extracted bleed flow is at a higher temperature than the compressor discharge flow (as is the case with port $3 \mathrm{~B}$ flow) then the coolant bleed fraction must be increased. Figure 7 shows the design point decrease in shaft power of baseline and wave rotor-enhanced turboshaft engines with parametrically varying cooling flow. The baseline and wave rotor-topped engines have a $C P R=8, T_{4 B}=2390 R$ $(1325 \mathrm{~K})$, and a mass flow rate of $5.0 \mathrm{lb} / \mathrm{s}(2.3 \mathrm{~kg} / \mathrm{s})$. Also shown (by the arrows) are the wave rotor-enhanced equivalent cooling percentages for the given baseline cooling percentages. The equivalent cooling percentage is based on the enthalpy of the peak pressure flow in wave rotor port 3B as this is where the cooling flow is most likely to be obtained for this four-port design. It can be seen that a baseline engine with $15 \%$ cooling flow has a shaft power of $514 \mathrm{HP}(383 \mathrm{~kW})$, while the corresponding wave rotor engine requires almost $20 \%$ of the higher temperature cooling flow to maintain the same turbine blade temperature and has 571 HP (426 $\mathrm{kW}$ ). As seen in the graph, the wave rotor-topped engines rapidly lose any performance benefit once the baseline cooling flow exceeds $20 \%$ due to the higher cooling flows required and the corresponding lower wave rotor pressure ratios.

The off-design performance benefit of wave rotor-topping is calculated using a turboshaft with $5 \%$ cooling flow as a baseline. The 
engine parameters are the same as those in Figure 7 and are listed in Table 1. This baseline engine is similar to small turboshaft engines which are primarily used in helicopter applications. Table 2 lists the performance data for the baseline and wave rotor turboshafts. At design the baseline engine is capable of delivering $599 \mathrm{HP}(447 \mathrm{~kW})$ and has a temperature ratio of 2.21 . The wave rotor designed for this engine has a pressure ratio of 1.24 without considering the penalty for cooling flow taken from the wave rotor. For a bleed flow of $5 \%$, the wave rotor pressure ratio falls to 1.21 but, as Fig. 7 shows, the wave rotor engine needs $7 \%$ bleed when coolant is taken from port 3B which reduces $\mathrm{PR}_{w}$ to 1.20 . At design, the wave rotor-enhanced turboshaft produces $709 \mathrm{HP}(529 \mathrm{~kW})$, or $18 \%$ more than the baseline. Both engines are run off-design to approximately $40 \%$ of maximum shaft power, and Figure 8 shows the specific fuel consumption and shaft power for the baseline and wave rotor-topped turboshafts. The graph shows that at off-design the wave rotortopped turboshaft behaves similar to the baseline; i.e., the SFC curves for the wave rotor engine and the untopped engine show the same trends. The off-design wave rotor pressure ratio decreases as the engine power and temperature is decreased. For the wave rotortopped engine at $84.5 \%$ power (comparable to the baseline engine full power), the wave rotor pressure ratio and fuel flow are 1.19 and $312 \mathrm{lb} / \mathrm{hr}(142 \mathrm{~kg} / \mathrm{hr})$, respectively. The inlet flow and $\mathrm{T}_{4 \mathrm{~B}}$ are 4.74 $\mathrm{lb} / \mathrm{s}(2.15 \mathrm{~kg} / \mathrm{s})$ and $2296 \mathrm{R}(1276 \mathrm{~K})$, respectively, at this point. In other words, for the same shaft power the wave rotor-enhanced engine has $13 \%$ less fuel flow, a $\mathrm{T}_{4 \mathrm{~B}} 94 \mathrm{R}(52 \mathrm{~K})$ cooler, and $6 \%$ lower air flow.

\section{Auxiliary Power Units}

Auxiliary power units are essentially a type of turboshaft engine. Rather than supply shaft power to a propeller, APU's for aircraft applications are typically used to supply both pressurized air to aircraft pneumatic and environmental control systems as well as supply shaft power to an electrical generator (Hoose, 1983). Other APU's, sometimes called small power units, are used to supply shaft power for various applications ranging from helicopter and tank engine starting to generators for mobile power systems.

APU's tend to have small mass flows ( $7 \mathrm{lb} / \mathrm{s}$ or less), low OPR's (around 4), and little if any turbine cooling. This makes them good candidates for wave rotor enhancement. Two cycle models are used to determine the benefits of wave rotor-topping of auxiliary power units. The first model uses the wave rotor as a high pressure spool in the engine core like the turboshaft engines previously discussed. The second model uses the wave rotor to replace the compressor and burner components of the APU. Figure 9 shows the schematics of the baseline and wave rotor-enhanced APU configurations.

The baseline APU cycle is of the integral bleed type. As shown in Tables 3 and 4, this APU is designed to supply $1.71 \mathrm{lb} / \mathrm{s}(0.775$ $\mathrm{kg} / \mathrm{s}$, or $28 \%$ of the compressor exit air) at $51 \mathrm{psia}(352 \mathrm{kPa})$ to the pneumatic systems while the turbine supplies power for the compressor and an additional $60 \mathrm{HP}(45 \mathrm{~kW})$ to run a generator. It has no cooling flow. Table 4 shows the performance data for the baseline and the wave rotor-topped auxiliary power units. Due to the low OPR of APU engines, the addition of the wave rotor increases shaft power immensely; for this cycle, the wave rotor-topped APU supplies $212 \%$ more shaft power than the baseline. Indeed, for many gas turbine cycles representative of auxiliary power units, the wave rotor-enhanced engines can easily double the available shaft power! Alternatively the wave rotor APU can be designed for the same shaft power, bleed mass flow, and bleed pressure as the baseline. Such an APU has $17 \%$ less intake mass flow than the baseline. Even with such substantial improvements, however, the additional weight and complexity of the wave rotor may overshadow the performance gain for this configuration.

The second wave rotor APU design consists only of the wave rotor (with burner) and a power turbine. The bleed air is taken from port $3 \mathrm{~B}$ and is at roughly $55 \mathrm{psia}(380 \mathrm{kPa})$. Ordinarily the wave rotor pressure ratio could be as high as 1.5 for this $\mathrm{TR}_{w}$, but the high amount of bleed flow reduces $\mathrm{PR}_{w}$ to about 1.24. However, this small pressure gain is enough for the power turbine to extract the 60 HP ( $45 \mathrm{~kW}$ ) needed to run the electrical generator. The wave rotor APU should weigh significantly less than the wave rotor-topped APU as the compressor component has been removed and the turbine has a much smaller expansion ratio. The disadvantage is that the fuel flow is $60 \%$ higher and the turbine corrected flow has substantially increased. Although it was not considered here, it is possible to design a wave rotor to provide shaft power instead of a pressure gain (i.e., a wave engine). Such a design may make it possible to remove the turbine from the APU cycle as well. Such an APU would consist only of a wave rotor/burner which has bleed taken from one duct and a shaft leading to a generator. Although its fuel consumption would be higher, this type of wave rotor APU has the potential for improvements in weight, manufacturing cost, and reliability and maintainability over a conventional auxiliary power unit.

\section{Ground Power Units}

Many ground power plants use gas turbine engines to supply shaft power to electrical generators. These ground power units are often turboshaft engines originally developed as aircraft powerplants. These engines are typically de-rated to extend their service time to the long hours necessary for economical operation (Cohen, et al., 1987). For these ground power units, the wave rotor can be used as a topping cycle similar to the turboshafts discussed previously. Tables 5 and 6 list the cycle and performance data for the baseline and wave rotor-enhanced ground power units. For the first cycle, the wave rotor pressure ratio is 1.20 and its addition increases the shaft power by $14 \%$. Alternatively, the wave rotor-topped ground power unit can supply the same power as the baseline with turbine inlet temperature reduced by $103 \mathrm{R}(57 \mathrm{~K})$, reducing fuel consumption by $10 \%$. This reduction in $\mathrm{T}_{4 \mathrm{~B}}$ significantly extends the useful life of the hot section components. In addition, with ground power plants it is assumed weight and size are not major factors. The wave rotor still adds complexity to the overall engine, however.

\section{Turbofan Engines}

For the turbofan engine, a baseline cycle representative of a current technology subsonic high-bypass separate-flow turbofan is chosen. The OPR and $T_{48}$ are 39 and $3200 \mathrm{R}$ (1778 K), respectively, for this cycle. Table 7 lists the values of the major design point variables. The wave rotor-enhanced turbofan uses the wave rotor pressure gain to increase engine thrust while keeping fuel flow constant relative to the baseline. Figure 10 is a schematic of the baseline and wave rotor turbofans. For the enhanced turbofan, the 
on-design wave rotor pressure ratio is 1.08 . This value takes into account the $20 \%$ cooling flow typical of modern turbofan engines. Note that for the four-port wave rotor design, the wave rotor turbofan requires a larger amount of cooling than the baseline for the same reason as the turboshaft engine discussed above. Preliminary studies indicate that for this turbofan cycle the cooling flow taken from the wave rotor port $3 \mathrm{~B}$ is too high in temperature to be effectively used for turbine cooling. Therefore it is assumed that the wave rotor cooling flow is at the same temperature as the baseline cooling flow. This assumption is reasonable if a wave rotor cycle can be designed to provide cooling air at a pressure just above $\mathrm{P}_{4 \mathrm{~B}}$ with a temperature close to $T_{3}$. A preliminary analysis of a five-port wave rotor design shows that this is feasible.

Table 8 lists the performance data for the turbofan cycles. The wave rotor-topped turbofan has its thrust increased by $2 \%$ at design by the wave rotor and its SFC is similarly decreased. The corrected flow into the high-pressure and low-pressure turbines is reduced by the increase in pressure created by the wave rotor and this has several effects. First, the weights of the HPT and LPT are decreased by $6 \%$ and $10 \%$, respectively; this translates into a $2-3 \%$ reduction in total engine weight. Second, the smaller turbine areas reduce the value of $\mathrm{AN}^{2}$ (which is proportional to blade pull stress) in both turbines by $8 \%$. It is difficult to predict the weight of the wave rotor due to its extreme pressures and temperatures and their unsteady nature. A preliminary weight calculation for this application indicates that the wave rotor and ducting weight (excluding the burner) is approximately $1650 \mathrm{lb}(750 \mathrm{~kg}$, or $25 \%$ of the baseline turbofan core weight).

The baseline and wave rotor-topped engines are run off-design for an envelope of altitudes and Mach numbers not exceeding $\mathrm{M}=0.85$ and $40000 \mathrm{ft}(12000 \mathrm{~m})$ with several engine throttle curves calculated at discrete Mach numbers and altitudes. This engine deck is used by the mission analysis code to interpolate engine performance at any Mach number, altitude, and throttle setting for the entire aircraft mission. For the wave rotor-enhanced turbofan, two cycle decks are created. The first has a $P R_{w}=1.08$, which is the predicted value based on the current analysis. The second cycle deck has a $\mathrm{PR}_{\mathrm{w}}=1.15$ which is chosen to show the aircraft TOGW sensitivity to increased wave rotor performance. This higher performance is attainable if the cooling flow is not taken from the wave rotor (e.g. the HPC flow is pressurized further and used for cooling). The baseline turbofan results in an aircraft takeoff gross weight equal to $588000 \mathrm{lb}(267000 \mathrm{~kg})$. Because the weight of the wave rotor is not precisely known, Figure 11 shows the relative TOGW of the aircraft with the wave rotor-topped turbofans as a function of the wave rotor weight. The addition of the wave rotor with a $\mathrm{PR}_{\mathrm{w}}$ of 1.08 reduces TOGW $2-5 \%$ depending on wave rotor weight. The higher performance wave rotor reduces aircraft TOGW an additional $3 \%$.

A variant turbofan cycle uses the wave rotor to replace stages of the high pressure compressor where the pressure gain from the wave rotor offsets the reduction in HPC pressure ratio. The thrust, SFC, and amount of turbine cooling of the wave rotor-enhanced turbofan cycle are kept the same as the baseline. Unfortunately, the wave rotor pressure ratio is so small that only the last stage of the 10-stage $\mathrm{HPC}$ can be removed. The turbine inlet temperature is lowered $41 \mathrm{R}$ $(23 \mathrm{~K})$ and the HPC pressure ratio is reduced from 15.8 to 14.2 for the wave rotor-topped turbofan. It is apparent that using the wave rotor to reduce the HPC pressure ratio will produce a significant weight penalty, but the lower $T_{41}$ will extend the life of the turbine components and may allow for lesser turbine cooling.

\section{Practical Integration and Technical Challenges}

There are a number of challenges presented by integrating a wave rotor with a gas turbine engine. Transition ducts which connect the annular flow compressor and turbine to the partial-annulus ports have to be carefully designed to avoid flow separation and high pressure losses; similarly, the ducts to and from the burner with their 180-degree turns must be designed to avoid severe pressure losses. In general, though, the design of these ducts is far from insurmountable. Furthermore, extraction of bleed flow from the wave rotor for turbine cooling should not add much complexity although it will decrease wave rotor performance.

There are other technical issues that have to be addressed. The wave rotor will require tight clearances to prevent leakage between the axial passages and the wave rotor end walls. Also, some mechanism must be used to maintain and regulate wave rotor rotational speed. Fortunately, it is expected that a wave rotor will have a rapid and stabilizing response to transient flow conditions, alleviating compressor surge in a topped engine (Taussig and Hertzberg, 1984). Some wave rotor designs have multiple cycles for each rotor revolution. These multiple cycles allow greater flexibility in design, but synchronization of each cycle may be a problem along with the increase in complexity from multiple ducts. Combustion inside the wave rotor axial passages is being studied (Nalim, 1995) in order to eliminate the separate burner, but the effect combustion-onthe-rotor has on variables such as fuel mixing, atomization, and ignition is not yet fully known.

Engines with high turbine inlet temperatures present the biggest challenge to practical implementation of a four-port wave rotor. These high $T_{41}$ cycles must supply cooling air to the turbines and, if the temperature is high enough, to the wave rotor as well. The wave rotor engines in this study have a $\mathrm{T}_{4}$ about $20 \%$ greater than the turbine inlet temperature, potentially requiring ceramics or other high temperature, high pressure materials in burner and outlet duct manufacture. If the wave rotor must supply cooling air to the turbines it will likely be taken from port $3 \mathrm{~B}$, where the temperature is approximately $25 \%$ greater than $\mathrm{T}_{3}$. Cycles with high $\mathrm{T}_{3}$ 's (and $T_{3 B}$ 's) can therefore require excessive and impractical amounts of cooling flow and the wave rotor pressure ratio then becomes almost negligible. The average rotor temperature is estimated to be approximately equal to the turbine inlet temperature, which means that the rotor itself could require cooling. The stresses in the wave rotor may be low enough, however, to allow for ceramics in its manufacture which could increase the allowable rotor temperature. Lastly, the peak pressure in the wave rotor is about 2.5-3.5 times $\mathrm{P}_{3}$; for modern engines this means WOPR's greater than 100 and potentially large weight penalties for designs strong enough to withstand such pressures.

\section{SUMMARY AND CONCLUSIONS}

The wave rotor is a proven technology. Cycle analysis has shown that a wave rotor can increase performance of practically any type of gas turbine engine. The amount wave rotor-topping increases 
performance depends not only on engine type but on engine specific design variables, primarily $O P R, T_{41}$, and the amount of cooling flow. Wave rotor performance is reduced when cooling flow is taken from the wave rotor, and wave rotor-topping is impractical for engines which require large ( $20 \%$ or higher) amounts of cooling flow to be extracted from the wave rotor itself. The wave rotor should be considered for individual applications on an engine specific basis.

Detailed studies are certainly in order to fully explore the potential of the wave rotor as part of an auxiliary power unit or turboshaft with low amounts of cooling flow. These studies should include the following: a) a detailed performance analysis of various wave rotor designs (e.g., a 5-port cycle) with an aim toward optimizing system performance realizing cooling flow may be required from the wave rotor; b) an analysis to calculate rotor stresses, weight, and temperature; c) a rotational speed analysis to determine how to regulate wave rotor speed; and d) a design (perhaps using CFD) of transition ducts to determine their pressure losses, flow characteristics, and their corresponding impact on turbine and wave rotor system performance.

\section{REFERENCES}

Cohen, H., Rogers, G. F. C., and Saravanamuttoo, H. I. H., 1987, Gas Turbine Theory, 3rd Edition, Longman Scientific and Technical with John Wiley and Sons, Inc., New York, NY, pp. 17-22.

Hoose, W., 1983, "APU Operational Efficiency," AGARD Conference Proceedings No. 352, Auxiliary Power Systems, pp. 13-1-15.

Klann, J. L., and Snyder, C. A., 1994, "NEPP Programmers Manual (NASA Engine Performance Program)," Vols. I and II, NASA Technical Memorandum 106575, NASA Lewis Research Center, Cleveland, $\mathrm{OH}$.

McCullers, L., 1984, "Aircraft Configuration Optimization Including Optimized Flight Profiles," Proceedings of the Symposium on Recent Experiences in Multidisciplinary Analysis and Optimization, NASA CP 2327.

Nalim, M. R., 1995, "Preliminary Assessment of Combustion Modes for Internal Combustion Wave Rotors," NASA Technical Memorandum 107000, NASA Lewis Research Center, Cleveland, OH. (Also AlAA-95-2801)

Onat, E., and Klees, G. W., 1979, "A Method to Estimate Weight and Dimensions of Large and Small Gas Turbine Engines," NASA CR 159481.

Paxson, D. E., 1993, "A Comparison Between Numerically Modeled and Experimentally Measured Loss Mechanisms in Wave Rotors," NASA Technical Memorandum 106279, NASA Lewis Research Center, Cleveland, OH. (Also AIAA-93-2522)

Shreeve, R. P., and Mathur, A. (editors), 1985, Proceedings of the 1985 ONRNAVAIR Wave Rotor Research and Technology Workshop, Report \# NPS-67-85-008, Naval Postgraduate School, Monterey, CA
Taussig, R., and Hertzberg, A., 1984, "Wave Rotors for Turbomachinery," ed. Sladky, J. F., Jr., Machinery for Direct Fluid Fluid Energy Exchange, AD-07, The American Society of Mechanical Engineers, New York, NY, pp 1-7.

Taussig, R. T., 1984, "Wave Rotor Turbofan Engines for Aircraft," ed. Sladky, J. F., Jr., Machinery for Direct Fluid - Fluid Energy Exchange, AD-07, The American Society of Mechanical Engineers, New York, NY, pp 9-45.

Welch, G. E., 1996, “Macroscopic Balance Model for Wave Rotors," NASA Technical Memorandum 107114, NASA Lewis Research Center, Cleveland, OH. (Also AIAA-96-0243)

Welch, G. E., Jones, S. M., and Paxson, D. E., 1995, "Wave RotorEnhanced Gas Turbine Engines," NASA Technical Memorandum 106998, NASA Lewis Research Center, Cleveland, OH. (Also AIAA95-2799) 
TABLE 1: Turboshaft Cycle Parameters

\begin{tabular}{|c|c|c|c|}
\hline & $\begin{array}{c}\text { Baseline Turboshaft } \\
\text { Design Point }\end{array}$ & $\begin{array}{c}\text { Wave Rotor Turboshaft } \\
\text { Design Point }\end{array}$ & $\begin{array}{c}\text { Wave Rotor Turboshaft } \\
\text { Oft-design, 85\% power }\end{array}$ \\
\hline inlet flow & $5.03 \mathrm{lb} / \mathrm{s}(2.28 \mathrm{~kg} / \mathrm{s})$ & $5.03 \mathrm{lb} / \mathrm{s}(2.28 \mathrm{~kg} / \mathrm{s})$ & $4.74 \mathrm{lb} / \mathrm{s}(2.15 \mathrm{~kg} / \mathrm{s})$ \\
\hline inlet recovery & 1.00 & 1.00 & 1.00 \\
\hline inlet temperature & $549.7 \mathrm{R}(305 \mathrm{~K})$ & $549.7 \mathrm{R}(305 \mathrm{~K})$ & $549.7(305 \mathrm{~K})$ \\
\hline compressor PR & 7.77 & 7.77 & 7.21 \\
\hline compressor efficiency & 0.81 & 0.81 & 0.80 \\
\hline compressor corrected flow & $5.18 \mathrm{lb} / \mathrm{s}(2.35 \mathrm{~kg} / \mathrm{s})$ & $5.18 \mathrm{lb} / \mathrm{s}(2.35 \mathrm{~kg} / \mathrm{s})$ & $4.88 \mathrm{lb} / \mathrm{s}(2.21 \mathrm{~kg} / \mathrm{s})$ \\
\hline cooling flow, \% & $5.0^{\circ}$ & $6.9^{6}$ & $6.9^{\mathrm{b}}$ \\
\hline wave rotor TR & - & 2.21 & 2.17 \\
\hline Iurbine inlet temperature & $2390 \mathrm{R}(1328 \mathrm{~K})$ & $2390 \mathrm{R}(1328 \mathrm{~K})$ & $2296 \mathrm{R}(1276 \mathrm{~K})$ \\
\hline GG turbine efficiency & 0.86 & 0.86 & 0.86 \\
\hline power turbine efficiency & 0.86 & 0.86 & 0.86 \\
\hline
\end{tabular}

$\because$ cooling flow at compressor exit temperature

b cooling flow at port 3B temperature

TABLE 2: Turboshaft Performance Results

\begin{tabular}{|c|c|c|c|}
\hline & $\begin{array}{c}\text { Baseline Turboshaft } \\
\text { Design Point }\end{array}$ & $\begin{array}{c}\text { Wave Rotor Turboshaft } \\
\text { Design Point }\end{array}$ & $\begin{array}{c}\text { Wave Rotor Turboshaft } \\
\text { Off-design, 85\% power }\end{array}$ \\
\hline wave rotor PR & - & 1.20 & 1.19 \\
\hline GG turbine expansion ratio & 2.87 & 2.88 & 2.86 \\
\hline GG turbine corrected flow & $1.45 \mathrm{lb} / \mathrm{s}(0.66 \mathrm{~kg} / \mathrm{s})$ & $1.19 \mathrm{lb} / \mathrm{s}(0.54 \mathrm{~kg} / \mathrm{s})$ & $1.19 \mathrm{lb} / \mathrm{s}(0.54 \mathrm{~kg} / \mathrm{s})$ \\
\hline power turbine expansion ratio & 2.30 & 2.75 & 2.56 \\
\hline power turbine corrected flow & $3.92 \mathrm{lb} / \mathrm{s}(1.78 \mathrm{~kg} / \mathrm{s})$ & $3.28 \mathrm{lb} / \mathrm{s}(1.49 \mathrm{~kg} / \mathrm{s})$ & $3.26 \mathrm{lb} / \mathrm{s}(1.48 \mathrm{~kg} / \mathrm{s})$ \\
\hline Shaft power & $599 \mathrm{HP}(447 \mathrm{~kW})$ & $709 \mathrm{HP}(529 \mathrm{~kW})$ & $600 \mathrm{HP}(447 \mathrm{~kW})$ \\
\hline Fuel flow & $357 \mathrm{lb} / \mathrm{hr}(162 \mathrm{kghr})$ & $354 \mathrm{lb} / \mathrm{hr}(161 \mathrm{~kg} / \mathrm{hr})$ & $312 \mathrm{lb} / \mathrm{hr}(142 \mathrm{~kg} / \mathrm{hr})$ \\
\hline Specific fuel consumption & $0.596 \mathrm{lb} / \mathrm{hr} / \mathrm{HP}$ & $0.499 \mathrm{lb} / \mathrm{hr} / \mathrm{HP}$ & $0.521 \mathrm{lb} / \mathrm{hr} / \mathrm{HP}$ \\
& $(0.362 \mathrm{~kg} / \mathrm{hr} / \mathrm{kW})$ & $0.304 \mathrm{~kg} / \mathrm{hr} / \mathrm{kW})$ & $(0.318 \mathrm{~kg} / \mathrm{hr} / \mathrm{kW})$ \\
\hline
\end{tabular}

TABLE 3: Auxiliary Power Unit Cycle Parameters

\begin{tabular}{|c|c|c|c|}
\hline & Baseline APU & $\begin{array}{c}\text { Wave Rotor APU } \\
\text { Topped Cycle }\end{array}$ & $\begin{array}{l}\text { Wave Rotor APU } \\
\text { No Compressor }\end{array}$ \\
\hline inlet flow & \multicolumn{3}{|c|}{$6.02 \mathrm{lb} / \mathrm{s}(2.73 \mathrm{~kg} / \mathrm{s})$} \\
\hline inlet recovery & \multicolumn{3}{|c|}{1.00} \\
\hline Inlet temperature & \multicolumn{3}{|c|}{$559.7 \mathrm{R}(311 \mathrm{~K})$} \\
\hline compressor PR & 4.0 & 4.0 & - \\
\hline compressor efficiency & 0.77 & 0.77 & - \\
\hline compressor corrected flow & $6.25 \mathrm{lb} / \mathrm{s}(2.83 \mathrm{~kg} / \mathrm{s})$ & $6.25 \mathrm{lb} / \mathrm{s}(2.83 \mathrm{~kg} / \mathrm{s})$ & - \\
\hline bleed flow, $\%$ & \multicolumn{3}{|c|}{28.4} \\
\hline Bleed flow rate & \multicolumn{3}{|c|}{$1.71 \mathrm{lb} / \mathrm{s}(0.775 \mathrm{~kg} / \mathrm{s})$} \\
\hline wave rotor TR & - & 2.30 & 3.73 \\
\hline turbine inlet temperature & $2086 \mathrm{R}(1159 \mathrm{~K})$ & $2086 \mathrm{R}(1159 \mathrm{~K})$ & $2085 R(1158 \mathrm{~K})$ \\
\hline turbine efficlency & \multicolumn{3}{|c|}{0.83} \\
\hline
\end{tabular}

TABLE 4: Auxiliary Power Unit Performance Results

\begin{tabular}{|c|c|c|c|}
\hline & Baseline APU & $\begin{array}{c}\text { Wave Rotor APU } \\
\text { Topped Cycle }\end{array}$ & $\begin{array}{c}\text { Wave Rotor APU } \\
\text { No Compressor }\end{array}$ \\
\hline wave rotor PR & - & 1.25 & 1.24 \\
\hline turbine expansion ratio & 3.26 & 4.13 & 1.09 \\
\hline turbine corrected flow & $2.34 \mathrm{lb} / \mathrm{s}(1.06 \mathrm{~kg} / \mathrm{s})$ & $1.83 \mathrm{lb} / \mathrm{s}(0.83 \mathrm{~kg} / \mathrm{s})$ & $7.27 \mathrm{lb} / \mathrm{s}(3.30 \mathrm{~kg} / \mathrm{s})$ \\
\hline Shaft power & $60.0 \mathrm{HP}(44.7 \mathrm{~kW})$ & $187 \mathrm{HP}(139.4 \mathrm{~kW})$ & $60.0 \mathrm{HP}(44.7 \mathrm{~kW})$ \\
\hline Fuel flow & $281 \mathrm{lb} / \mathrm{hr}(127 \mathrm{~kg} / \mathrm{hr})$ & $281 \mathrm{lb} / \mathrm{hr}(127 \mathrm{~kg} / \mathrm{hr})$ & $449 \mathrm{lb} / \mathrm{hr}(204 \mathrm{~kg} / \mathrm{hr})$ \\
\hline Bleed flow pressure & $51.0 \mathrm{psia}(352 \mathrm{kPa})$ & $51.0 \mathrm{psia}(352 \mathrm{kPa})$ & $54.8 \mathrm{psia}(378 \mathrm{kPa})$ \\
\hline
\end{tabular}


TABLE 5: Ground Power Unit Cycle Parameters

\begin{tabular}{|c|c|c|c|}
\hline & $\begin{array}{c}\text { Basellne Ground } \\
\text { Power Plant }\end{array}$ & $\begin{array}{l}\text { Wave Rotor Ground } \\
\text { Power Plant - Design A }\end{array}$ & $\begin{array}{l}\text { Wave Rotor Ground } \\
\text { Power Plant - Design B }\end{array}$ \\
\hline Inlet flow & \multicolumn{3}{|c|}{$220 \mathrm{lb} / \mathrm{s}(100 \mathrm{~kg} / \mathrm{s})$} \\
\hline compressor pressure ratio & \multicolumn{3}{|c|}{10.0} \\
\hline compressor efficiency & \multicolumn{3}{|c|}{0.84} \\
\hline cooling flow, $\%$ & \multicolumn{3}{|c|}{1.0} \\
\hline wave rotor TR & - & 2.08 & 1.98 \\
\hline turbine inlet temperature & $2250 \mathrm{R}(1250 \mathrm{~K})$ & $2250 \mathrm{R}(1250 \mathrm{~K})$ & $2147 \mathrm{R}(1193 \mathrm{~K})$ \\
\hline GG turbine efficlency & \multicolumn{3}{|c|}{0.90} \\
\hline Power turbine efficlency & \multicolumn{3}{|c|}{0.91} \\
\hline
\end{tabular}

TABLE 6: Ground Power Unit Performance Results

\begin{tabular}{|c|c|c|c|}
\hline & $\begin{array}{c}\text { Baseline Ground } \\
\text { Power Plant }\end{array}$ & $\begin{array}{c}\text { Wave Rotor Ground } \\
\text { Power Plant - Design A }\end{array}$ & $\begin{array}{c}\text { Wave Rotor Ground } \\
\text { Power Plant - Design B }\end{array}$ \\
\hline wave rotor PR & - & 1.20 & 1.17 \\
\hline GG turbine expansion ratio & 3.06 & 3.06 & 3.27 \\
\hline Power turbine exp, ratio & 3.04 & 3.66 & 3.33 \\
\hline Shaft power & $33550 \mathrm{HP}$ & $38210 \mathrm{HP}$ & $33550 \mathrm{HP}$ \\
& $(25.0 \mathrm{MW})$ & $(28.5 \mathrm{MW})$ & $(25.0 \mathrm{MW})$ \\
\hline Fuel flow & $14220 \mathrm{lb} / \mathrm{hr}$ & $14220 \mathrm{lb} / \mathrm{hr}$ & $12840 \mathrm{lb} / \mathrm{hr}$ \\
& $(6450 \mathrm{~kg} / \mathrm{hr})$ & $(6450 \mathrm{~kg} / \mathrm{hr})$ & $(5820 \mathrm{~kg} / \mathrm{hr})$ \\
\hline
\end{tabular}

TABLE 7: Turbofan Cycle Parameters

\begin{tabular}{|c|c|c|c|}
\hline Design Variable & Baseline Engine & $\begin{array}{l}\text { Wave Rotor Engine } \\
\text { Design } A: P R_{2}=1.08\end{array}$ & $\begin{array}{l}\text { Wave Rotor Engine } \\
\text { Design B: } P R=1.15\end{array}$ \\
\hline inlet flow & \multicolumn{3}{|c|}{$2800 \mathrm{lb} / \mathrm{s}(1270 \mathrm{~kg} / \mathrm{s})$} \\
\hline inlet recovery & \multicolumn{3}{|c|}{1.00} \\
\hline inlel lemperature & \multicolumn{3}{|c|}{$545.7 \mathrm{R}(303 \mathrm{~K})$} \\
\hline bypass ratio & \multicolumn{3}{|c|}{7.00} \\
\hline $\operatorname{fan} P R$ & \multicolumn{3}{|c|}{1.59} \\
\hline fan efficlency & \multicolumn{3}{|c|}{0.91} \\
\hline fan corrected flow & \multicolumn{3}{|c|}{$2875 \mathrm{lb} / \mathrm{s}(1304 \mathrm{~kg} / \mathrm{s})$} \\
\hline LPC PR & \multicolumn{3}{|c|}{1.55} \\
\hline LPC efficiency & \multicolumn{3}{|c|}{0.88} \\
\hline HPC PR & \multicolumn{3}{|c|}{15.8} \\
\hline HPC efficiency & \multicolumn{3}{|c|}{0.85} \\
\hline HPT inlet temp. & \multicolumn{3}{|c|}{$3200 \mathrm{R}(1778 \mathrm{~K})$} \\
\hline bleed flow, $\%$ & \multicolumn{3}{|c|}{19.5} \\
\hline wave rotor TR & \multicolumn{3}{|c|}{1.91} \\
\hline HPT efficiency & \multicolumn{3}{|c|}{0.89} \\
\hline LPT efficiency & \multicolumn{3}{|c|}{0.93} \\
\hline
\end{tabular}

TABLE 8: Turbofan Performance Results

\begin{tabular}{|c|c|c|c|}
\hline & Basellne Engine & $\begin{array}{c}\text { Wave Rotor Engine } \\
\text { Design A: PR=1.08 }\end{array}$ & $\begin{array}{c}\text { Wave Rotor Engine } \\
\text { Design B: } P R_{w}=1.15\end{array}$ \\
\hline wave rotor PR & - & 1.08 & 1.15 \\
\hline HPT expansion ratio & 4.87 & 4.87 & 4.87 \\
\hline HPT corrected flow & $19.8 \mathrm{lb} / \mathrm{s}(8.98 \mathrm{~kg} / \mathrm{s})$ & $18.2 \mathrm{lb} / \mathrm{s}(8.26 \mathrm{~kg} / \mathrm{s})$ & $17.0 \mathrm{lb} / \mathrm{s}(7.71 \mathrm{~kg} / \mathrm{s})$ \\
\hline LPT expansion ratio & 5.15 & 5.15 & 5.15 \\
\hline LPT corrected flow & $96.0 \mathrm{lb} / \mathrm{s}(43.5 \mathrm{~kg} / \mathrm{s})$ & $87.9 \mathrm{lb} / \mathrm{s}(39.9 \mathrm{~kg} / \mathrm{s})$ & $82.1 \mathrm{lb} / \mathrm{s}(37.2 \mathrm{~kg} / \mathrm{s})$ \\
\hline Net thrust & $86820 \mathrm{lb}(386 \mathrm{kN})$ & $88370 \mathrm{lb}(393 \mathrm{kN})$ & $89470 \mathrm{lb}(398 \mathrm{kN})$ \\
\hline SFC & $0.313 \mathrm{lb} / \mathrm{hr} / \mathrm{b}$ & $0.308 \mathrm{lb} / \mathrm{hr} / \mathrm{b}$ & $0.304 \mathrm{lb} / \mathrm{hr} / \mathrm{b}$ \\
& $0.0319 \mathrm{~kg} / \mathrm{hr} / \mathrm{N}$ & $0.0314 \mathrm{kghm} / \mathrm{N}$ & $0.0310 \mathrm{~kg} / \mathrm{hr} / \mathrm{N}$ \\
\hline Engine weight & $20430 \mathrm{lb}$ & $19990 \mathrm{lb}+$ wave rotor & $19470 \mathrm{lb}+$ wave rotor \\
& $(90.9 \mathrm{kN})$ & $(88.9 \mathrm{kN})+$ wave rotor & $(86.6 \mathrm{kN})+$ wave rotor \\
\hline
\end{tabular}



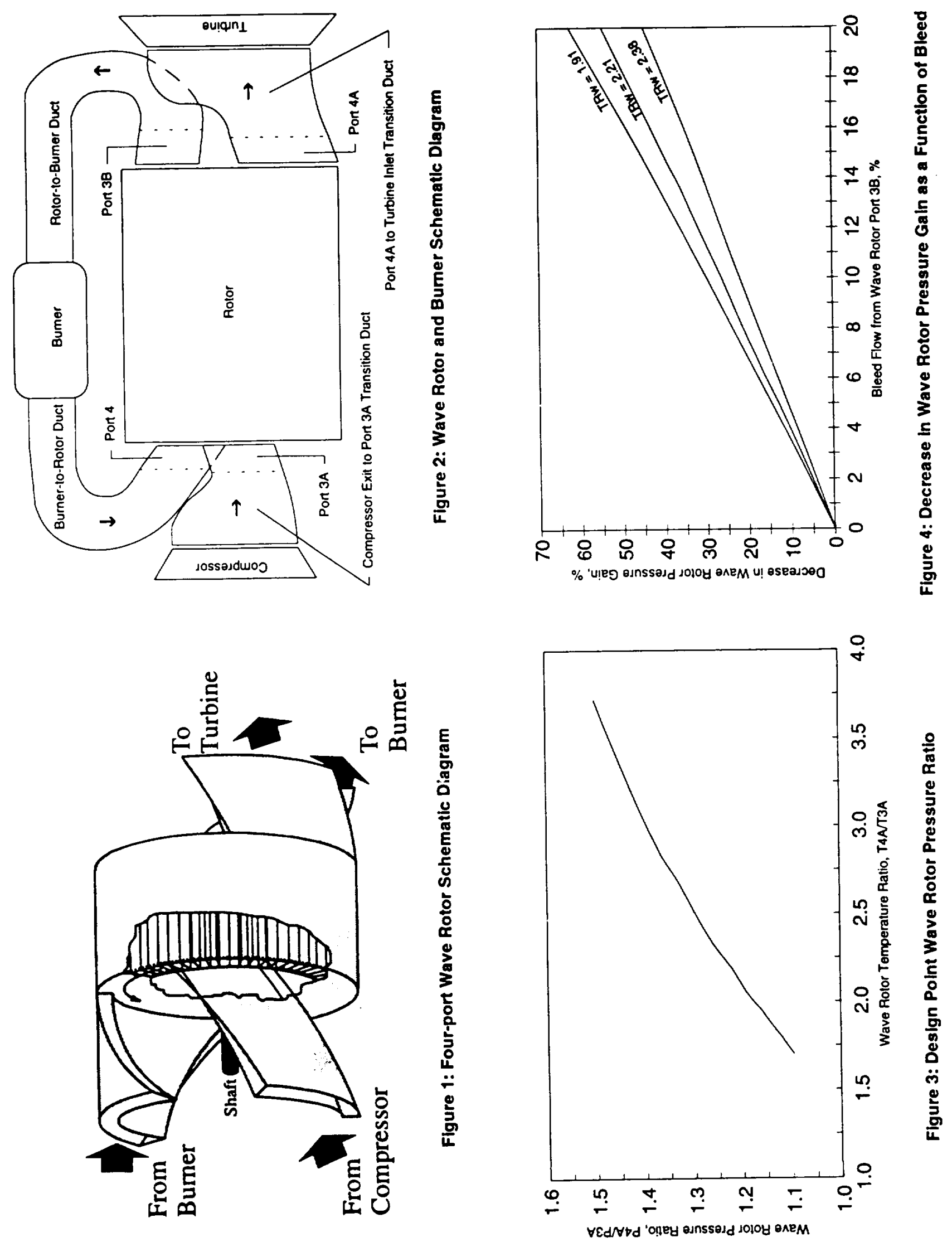

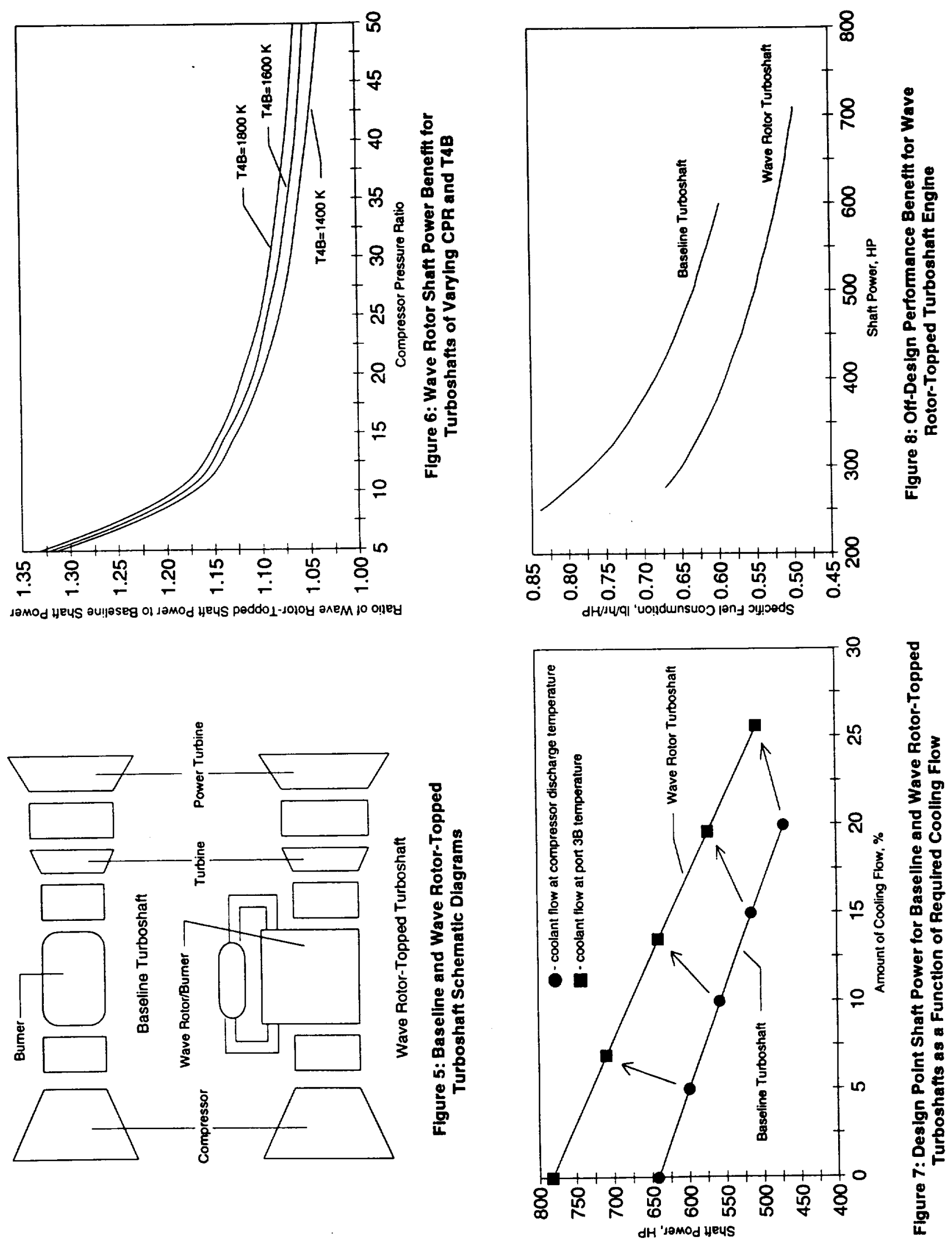

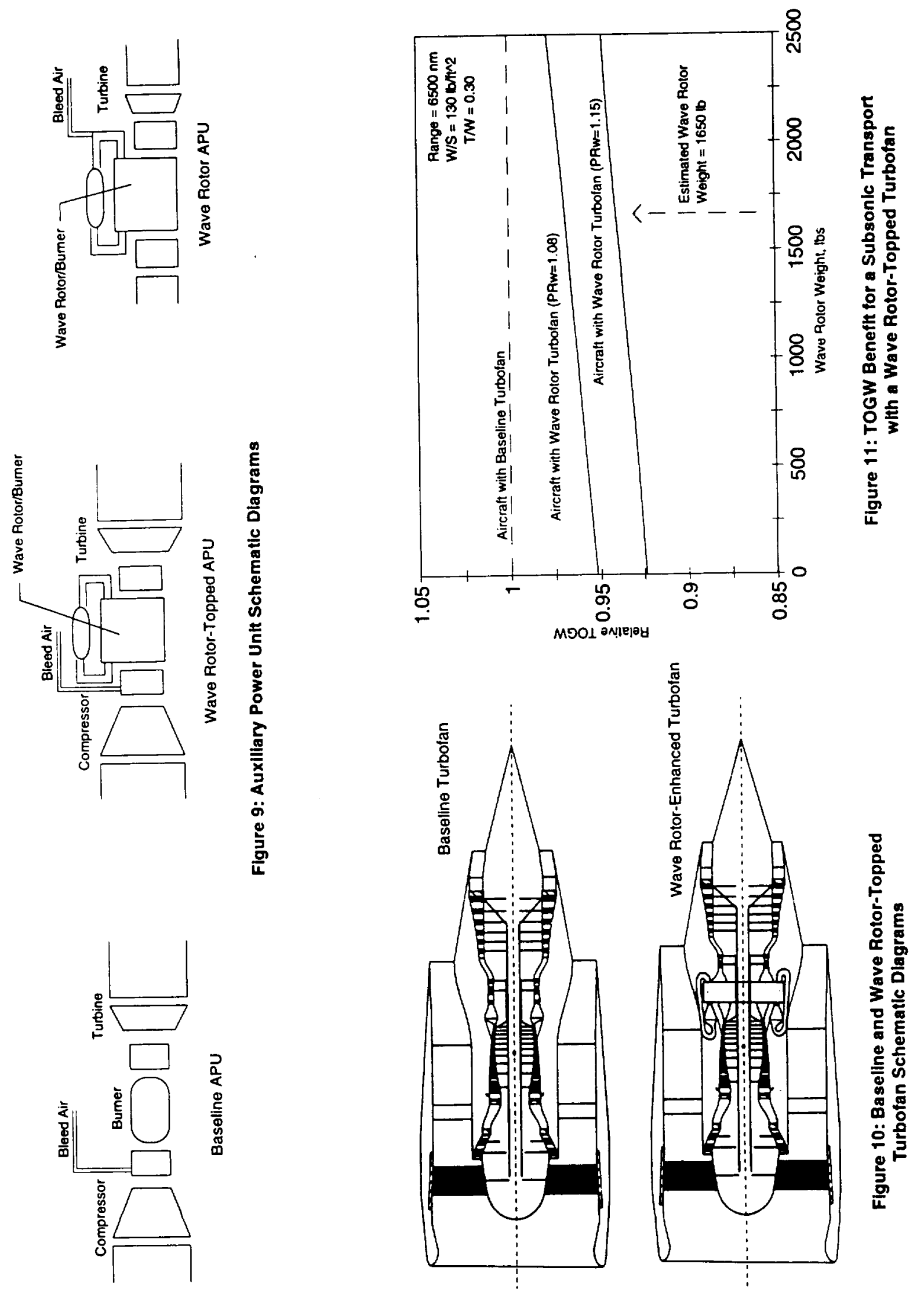


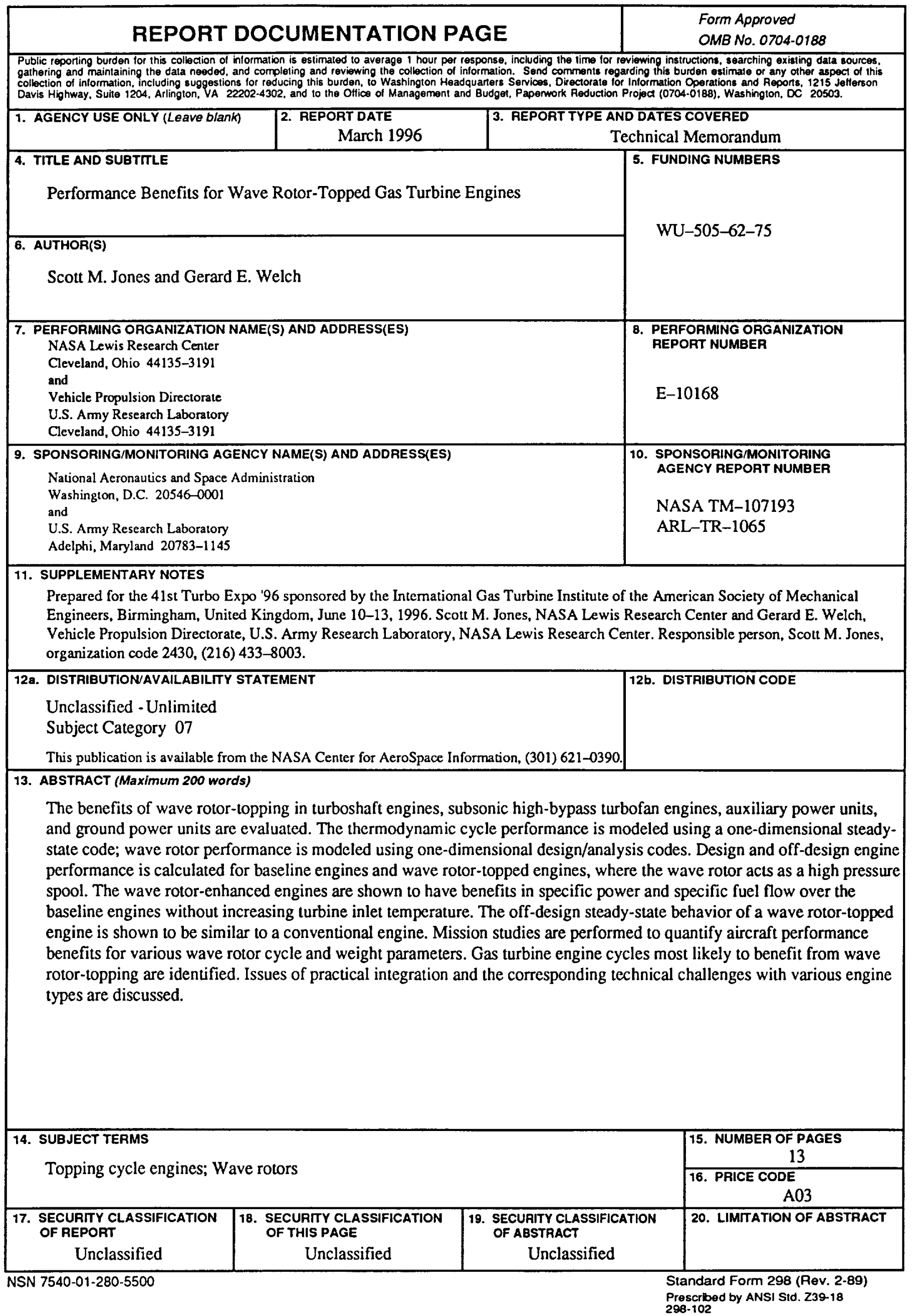




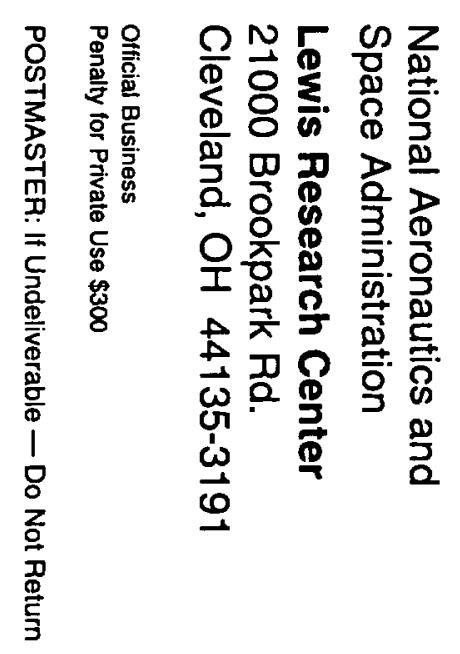


